\title{
The Rise of Indian English and the Renaissance in Modern Indian Literature
}

\author{
Latha Velavan
}

\begin{abstract}
This article is about The Rise of Indian English and The Renaissance in Modern Indian Literature. This also brings in to light how the Indian Novel in English came into existence during the British rule in India. The History of English literature in our country come forth when English people entered into Hindustan in the name of trading. Inorder to overcome the problem of communication in an alien land the Englishmen pleaded for the adoption of their Language. In the long uneasy and interminable task of making English as an Indian language, Mohandas Karamchand Gandhi and Jawaharlal Nehru were the central figures.
\end{abstract}

(Key words: Adoption, Alien land, Interminable, Central Figures, Pleaded, Existence)

\section{THE RISE OF INDIAN ENGLISH}

Indian Writing in English came into existence during the period of East India Company in India, but the true flowering began to take place after the independence. English is treated today as either as an official or a second language due to its popularity amongst the India's population. This is precisely because India had been a colony of the British Empire for close to 300 years. The entry of Englishmen happened in the year 1608 because of the Mughal Emperor Jahangir, when he received the British Naval Expedition Hector Captain William Hawkins to his court. It was India's first assignation with an English men and their language.

Later, the Emperor permit the British to open a stable port and an industry on a special quest from his friend King James IV, later it was conveyed by his ambassador, Sir Thomas Roe. Thus English started spreading its wings and their stay had become an eternal one.

In order to overcome the problem of communication in an unknown land, one of the directors of East India Company, Charles Grant, requested in 1792 for the adoption of the English language. This was a solid step to seek foothold. By the beginning of 17th century, the Englishmen started ruling India vigorously. In 1813, the Englishmen besides public functions, started educating and influencing people through writings in English.

Along with the books, the printing presses also brought in to existence. It gave a new rise to the first ever newspaperHicky's Bengal Gazette (1780) and the others followed in due course. And then, they started the introduction of private schools which imparted only English Education. Slowly people became slave to the new life and language, so the interest towards Western education spread faster than expected. The love for English rapidly increased between 1835 - 1855. It was reported that during this period 32,000

Revised Version Manuscript Received on 10 September, 2019. India.
English books were sold against 13,000 Indian language books.

Forty three years later, the new language was accepted with a small declaration by the Governor in Council for the promotion of European literature and science amongst Indians. The annual report of the Registrar of newspapers for India for the year 1957, informed that nearly more than 50 English newspapers were existed in India while as many as the same in all other Indian languages put together. The circulation of English papers were 1,005,000, while that of 57 Hindi newspapers had an aggregate circulation of only 394,000.

English newspapers, as a rule, were not only better edited but were also read all over the country, whereas the Hindi reading public was confined to parts of North India. Again, it is an interesting fact that there were seven times more quarterly journals in English as compared to Hindi and as many in English as in almost all the other languages put together. The love towards the European language increased day by day. The alien language suddenly got a special pace and spreads its wings even in the government offices. .All educated people across the country started using the language in order to gain a new magnetism from the public. The language apprehended the significant place in almost all the Educational Institutions. The reasons to impose the new language is not to constrain the condition of Hindustan but to gain the trust of Indians. It was also one of the deceitful action of colonizers.

M. E. Derrett states and believes that the British's aim was not to educate and improve the standards of Indians. They needed a good translators to carry their official work for that they should made the Indians to familiarize with some Western ideas and manners. So they tried and succeeded in their own way. Apart from translators, they were in need of persons to carry their clerical works so they asserted the western education and made the people to believe that the new education system was a better one than that of their own.

The demand for the innovative language steadily developed amongst Indians. People slowly started succeeding the western manners and customs. The first railway and first telegraph line were established in this period only. People welcomed these new developments and started enjoying their modern facilities. With reading, comprehending and speaking, people started writing in English too. In the beginning people were using folks and myths for their writing because India has been the land of tales for so many years. The above facts made the Indian

Published By:

Blue Eyes Intelligence Engineering

\& Sciences Publication 
writing in English a renowned one. They utilized prose and determined verse even epics for their writings. Everywhere the new creative urge for learning was visible. This period was known as the revolutionary period of Indians, and it is referred as the period of literary renaissance.

Indian English refers to the body of work by the Hindustani, whose mother tongue could be one among Indian languages. It has just one and half century old and compared to other languages it has only recent history. The first book in english was by Sake Dean Mohammed who wrote about the travels of his own and he named it as "Travels of Dean Mohamed". In 1793, it was published in England because it followed the Western writing in many places. In the beginning, Indian writing in English was difficult because writers failed to alter words to certain extent. They struggled to use a new-fangled vocabulary which was a great expectation of the British people.

At the early of 20th century, when the English men conquered India thoroughly, a new class of writers were emerged. Those new writers were British people, who were born and brought up in India. They wrote on the themes and manners of India in their own style. But they didn't received much appreciation because the writers couldn't make Indianness in their story telling. Rudyard Kipling, Jim Corbett and George Orwell and others were representing these new breed of British writers. In fact some of their writings are still considered to be the masterpieces of English literature.

The number of fictional writers was more in the year 1947. They were classified into two groups. Primarily the English writers who wrote for their own people, and their writings aimed to entertain and educate the Englishmen. Many English writers were inspired by Indian themes, culture and history. In fact many colonizers tried to internalize the culture of India in their writings. But they failed in their attempts because they could never be authentic though they wanted to present everything through their experience. Some of the texts written by the colonizers become very popular in the world wide — such as 'The Jungle Book' written by Rudyard Kipling, or Paul Scott's 'Tetralogy, The Jewel in the Crown', both popular as novels, as well as film adoptions.

\section{THE RENAISSANCE IN MODERN INDIAN LITERATURE\& RESULTS}

The Renaissance in Modern Indian literature initiated with Raja Ram Mohan Roy. He was born in Radhanagar village in West Bengal, Hooghly district, on May 22, 1772. In 1803, he secured a job with the East India Company. To fulfil his goal he shifted his place to Calcutta. But he wasn't happy with the education system and the method of teaching so along with his friends, he formed an association of English with Hindu Scholars. He started introducing subjects like Science, Mathematics, Political Science and English in his own school.

Raja Ram Mohan Roy felt that the new subjects introduced by him would give a better place and understanding for his own people. People began to display increasing confidence in handling the English tongue, and subsequently, English became the medium of self-expression in the lives of the intellectuals. Later Raja Ram started social reform programmes and spreads the culture value of India in British publications.

In the beginning, the Indians reacted with suspicion that the new language may create a cultural fabric in their own country but gradually they realised the situation and welcomed with open minds. The 1930s generally seemed as the take-off decade for the Indian novels in English, people can trace its genealogy quite far back in the previous century. In the 17 th century the printing press was introduced but the publication were largely of printing the Bible or the government decrees. The real freedom of English education came into being because of Raja Ram Mohan Roy. He was named as the first Indian Masters of the English Prose. Not only in fiction he was great in many other fields too.

In the nineteenth century, the position of English underwent a tremendous change, even the language of administration and law remind in English. The medium of teaching and examination in most colleges and universities were also in English. Between 1835 and 1855, the number of those educated in English had been rapidly increased and the number of Englishmen in India too.

People's love for English books increased and they started following them in customs, dress, eating habits, in salutations and it is said that the popular Indian city, Lucknow in 1824 had the look of a European city because of the people's western manners. The interest towards the new western style made parents to send their children to new missionary schools. It is said that Rabindranath Tagore's father, Maharshi Debendranath, went from house to house, morning till evening, entreating Hindu Parents not to send their children to missionary schools but only to native schools.

It is no secret that the English language faced criticisms from the beginning. According to R. Chandra Sekaran (12), English is the veritable Suez Canal for intellectual intercourse between the West and the East, between England and India especially. From Vedic to modern times the eminent Indian thinkers, Raja Ram Mohan Roy, Keshub Chunder Sen, Swamy Vivekananda, Tagore, Sri Aurobindo, Gandhi, and Dr. S. Radha Krishan - all of them made themselves heard in the West through their mastery over English language.

Western education had become the gateway to knowledge, freedom and power. It cut the old bonds of convention and tradition and it made a new world and new life possible. English became the medium of self- expression in the lives of the intellectuals. The restoration of Indian Classical learning and the study of European arts and science gave rise to an extraordinary arousing in India. More and more books were published by Indo-Anglican authors who focused on fellow Indians as well as on foreign audience:

By the late nineteenth century the Indian reading public had already divided and authors were writing as much to arouse Indians as to impress and interest the westerners. For the first time they were able to communicate with an educated élite in their own country - one might venture to call them a sub-caste-besides interesting some people outside India (Derrett 18). 
M. E. Derrett suggest that, the growing of English speaking people soon became an inspiration for aspiring Indian authors to write in English. The rapid increase in number of English readers in India created more number of Indian authors. The official language of the colonisers gave a new way to number of new literary genres which India was yet to discover and exploit.

For the first time in India, a middle class intellectuals began to emerge from the feudal society and it gave a rise to an intense nationalism, during which the Indians struggled to articulate their passionate thoughts and feelings. Writers like Bankim Chandra Chatterjee, Swami Vivekananda, Dinabandu Mitra and Sarachandra Chatterjee caught up in the provincial patriotism, and revived the regional languages, whereas others believed that the English rule had come to stay. So they studied and used the language of the rulers, which gave a fresh rise to a new genre of Indian English, initially termed as Anglo-Indian literature.

The books like The Rig Veda and the Upanishads, The Thirty Two Stories of the Throne, Somadeva's Kathasarithsagara, Arthasastra were translated into English. Not only the literary giants but even the spiritualists like Swami Vivekananda and Sir Aurobindo amazed the English speaking people with their fluency, ease and consummate mastery of English language.

In the long, uneasy and interminable task of making English as an Indian language, Mohandas Karamchand Gandhi and Jawaharlal Nehru were the central figures. Each took the alien language of the rulers and found ways to make it intimate, fluent and comprehensible. Gandhi was a humanist and a man of religion more than a nationalist and a patriot. Though Gandhi worked for the liberation of India from the foreign rule, there was no hatred in his heart for the British and their language. He hoped that Hindustani might one day become the lingua franca of the country, so he continued to write and speak in English and was fully sensible of the advantage of knowledge of that great world language.

With the Gandhian revolution in our political life, there came about also a revolution in Indian writing. Gandhi was not in sympathy with the view that art or literature was absolutely autonomous, and was far more inclined to make it a handmaid for life. Like Tolstoy, Gandhi too felt that authors are not to a particular autonomy and pre-eminence. Their relentless support was a great reprieve to some writers who ruminate their life for the sake of art.

Gandhi wrote both in Gujarati and in English. Under the influence of his writings many new writers flourished with their regional languages. Gandhi's writing were noted for simplicity and clarity. He himself knew that he wasn't a great scholar but never feels for it. Epics, lyrics, dramas and fables had their respectable ancestries, going back by several centuries. But the 'Novel' a long sustained piece of prose fiction occurred and took its root in India only very late.

\section{THE RISE OF ENGLISH NOVEL IN INDIA}

The journey of English novel had begun with a bash when Rabindranath Tagore was bestowed with the Nobel Prize for literature. By the time V.S. Naipaul was also awarded with the Nobel Prize. Thus Indian English has captured a far flung reach. The very eternal trend was held strongly, soon after by the publication of Rabindranath Tagore's spiritual prose "The Gitanjali" and by the Preachings of Mahatma Gandhi.

But, unfortunately, poetry and drama for which India is known better to the world from time immemorial, are not getting due attention when compared to fiction. The Indian novel in English in its brief history has always been concerned with defining a national identity. The three pioneering novelists, Raja Ram Mohan Roy, Mulk Raj Anand, and R. K. Narayanan have lost none of their authenticity and appeal in the 90s, although their distinctive earlier works appeared in the 30s.

Raja Ram Mohan Roy was known as the Master of Modern India. Roy's works are deeply rooted in Brahmanism and Hinduism. His semi-autobiographical novel, The Serpent and the Rope (1960), is a story of a search for spiritual truth in Europe and in India. Roy's India is not a certain geographical or historiographical entity, but more of a philosophical concept and a symbol of spiritual calling.

R.K. Narayan though he writes in English, his thoughts, feelings, the stirrings of the soul and consciousness are all of the soil of India. Through his writings, he gave unaccustomed people a broad window to peep into Indian culture and sensibilities. He is one of the few writers in India who took their craft seriously and are dependably striving to improve the standards of the life of the suffering Indians. He is a master of comedy and a critic of life and literature as well.

Mulk Raj Anand as a writer of fiction has his notable marks of vitality and a keen sense of actuality. He is admired for his novels and short stories which have acquired the status of being classic works of modern Indian English Literature. These three writers, in their own special ways, became significant for the later growth and development of Indian novel writing.

\section{REFERENCES}

1. Marx, John. "Postcolonial Literature and the Western Literary Canon" The Cambridge Campanion to Postcolonial Literary Studies. Ed. Neil Lazarous. Cambridge: Cambridge UP.

2. Derret.M.E."The Modern Indian Novel in English: A Comparative Approach".

3. Sekaran Chandra R. "Indian Writing in English" Erode: Pallavi Pathippagams India (P) Ltd., 2008.

4. Forbes, Geraldine. Women in Modern India. Cambridge: Cambridge University Press, 1999.

5. Rama Kant Agnihotri and Rajendra Singh. "Indian English towards A New Paradigm". Orient Black Swan Private Limited., 2012.

6. Amar Nath Prasad. "New Lights on Indian Women Novelists in English". Sarup \& Sons., 2003. 